\title{
Physiological Standards of Acoustic Rhinometry in Suez Canal Area
}

\author{
Amani A Elbaz*, Alaa Fareed**, Magdy A Elbarbary*, \\ and Sahar M Greish* \\ *Department of Physiology, Faculty of Medicine, Suez Canal University \\ ** Department of ENT, Faculty of Medicine, Suez Canal University
}

\begin{abstract}
Acoustic Rhinometry (AR) measures the relationship of the cross-sectional area and the distance into the nasal cavity. Great efforts have been done to validate and standardize its clinical use. Inspite of many researches done in Egypt by AR, there are no normal National Egyptian Physiological gold standards of MCA, DMCA and NCV like many other countries. This study was carried out to establish local reference values for AR parameters in healthy normal adults. One hundred and thirty healthy volunteer students of the Faculty of Medicine, Suez Canal University in the age range from 18 to 24 years, who were free from any nasal problems by history and examination, were subjected to AR testing in the Department of Otorhinolaryngology, Suez Canal University Hospital. The AR parameters before decongestant were: mean mMCA was $0.58 \pm 0.15 \mathrm{~cm}^{2}$ with a range $0.27-1.00 \mathrm{~cm}^{2}$, the mean $m D M C A$ was 1.92 $\pm 0.16 \mathrm{~cm}$ with a range $1.62-2.34 \mathrm{~cm}$, and the mean total $N C V$ was $12.68 \pm 3.35 \mathrm{~cm}^{3}$ and ranges from 5.11 to $21.97 \mathrm{~cm}^{3}$. The AR parameters after decongestant was: mean mMCA was $0.60 \pm 0.14 \mathrm{~cm}^{2}$ with a range $0.31-1.14 \mathrm{~cm}^{2}$, the mean $m D M C A$ was 1.90 $\pm 0.16 \mathrm{~cm}$ with a range $1.50-2.46 \mathrm{~cm}$, and the mean total NCV was $13.32 \pm 3.79 \mathrm{~cm}^{3}$ and ranges from 5.46 to $26.41 \mathrm{~cm}^{3}$. It was found that the difference between males and females in the three AR parameters was statistically significant before and after decongestion. Also, it was found that there were weak positive significant correlations between the three AR parameters and height, weight and age before and after decongestion. In this study, it was found that there were insignificant relations between the AR parameters and the sensation of nasal cycle and the phases of menstrual cycle, but there was a significant relation between the AR parameters and the performance of sport activity, so other researches are needed to study the effect of nasal cycle, hormonal changes, sport activity, effect of nasal infections and pulmonary functions on the AR parameters.
\end{abstract}

Key words: Acoustic Rhinometry- Nasal cavity dimensions

\section{INTRODUCTION}

The nose is the guardian angel of the respiratory tract. It has several important physiological functions which include air-conditioning, filtering inspired air, and smell. The nasal mucosa also has an important immunologic role in defending against inhaled foreign pathogens and allergens. To serve these important functions, a patent nasal passage is needed ${ }^{1}$. 
Acoustic rhinometry is a new and simple method for assessment of nasal airway dimensions. An audible sound signal generated at the bottom of a tubular probe is transmitted into the nasal cavity via an anatomically fitted nosepiece. An area-distance relationship describing the airway geometry is created by comparing the incident and the reflected sound signal.

The technique is quick, accurate, reproducible, non-invasive, has no adverse effects, is independent of airflow, and requires minimal cooperation from the subject. Several recent studies have established acoustic rhinometry as an important investigative tool in rhinology. It is well suited to illustrate normal physiology of the nasal mucosa, to document deleterious effects of exposure to irritants and to monitor the effect of surgical and medical therapy. A newly developed miniprobe has proven to be uniquely suited for studying the nasal airways of infants and small children ${ }^{2}$.

A graph of nasal cross-sectional area as a function of distance from the nostril is produced, from which several area and volume estimates of the nasal cavity can be derived. The reliability of the method is greatest in the anterior nasal cavity, which is the site of the nasal valve ${ }^{3}$.

Acoustic rhinometry evaluates the geometry of the nasal cavity with acoustic reflections and provides information about nasal crosssectional area and nasal volume within a given distance. Variations in internal nasal diameters have attracted increased interest since the advent of endoscopic surgical techniques. Race is known to be one of the most important factors affecting the nasal structure $^{4,5}$.

Nasal symptoms often are in consistent with rhinoscopic findings. However, the proper diagnosis and treatment of nasal pathology requires an objective evaluation of the narrow segments of the anterior part of the nasal cavities (minimal crosssectional area [MCA]). The problem is that the value of MCA is not a unique parameter for the entire population, but rather it is a distinctive value for a particular subject (or smaller groups of subjects). Consequently, there is a need for MCA values to be standardized in a simple way that facilitates the comparison of results and the selection of the treatment regimens $^{6}$.

Acoustic rhinometry is a new objective rhinometric method, but different races must have their standards respectively ${ }^{1,7}$.

The aim of this study was to establish physiological gold standard parameters of acoustic rhinometry of young adults in Suez Canal area.

\section{SUBJECTS \& METHODS}

130 normal adult volunteers were subjected to the study. Their age ranged between 18-24 years. All were medical students in the faculty of medicine, Suez Canal University. We excluded any history of smoking, suffering from any nasal pathologic conditions or taking medications such as decongestants, antihistaminics or aspirins.

The acoustic rhinometry was performed using PC-based Eccovision 
${ }^{\circledR}$ system (Model AR- 1003) from Hood Laboratories Inc., Pembroke, MA, USA . This system uses amplitudes and arrival times of echoes to construct the acoustic rhinogram which represents the entire nasal cavity as a function of distance from the nostrils.

The device consists of a sound source (loudspeaker) mounted at the distal end of the wave tube (inside diameter: $1.27 \mathrm{~cm}$ ) with a recording microphone at the proximal end of the tube (speaker to microphone distance: $20 \mathrm{~cm}$ ). The loud speaker emits an audible signal of $150-10000 \mathrm{~Hz}$ that propagates down the wave tube. It passes the microphone and enters the nasal cavity. The incident and reflected acoustic signals are registered by the microphone. The distance between the microphone and the nose is $4 \mathrm{~cm}$. The analog signal is amplified, low pass filtered and digitized at a sampling rate of $70 \mathrm{kHz}$. The data were processed using the PC-based software to generate an area distance function. The latter is calculated as the mean of 10 serial measurements with 0.2 second delay between them.

Before each measurement, the rhinometer is calibrated with a calibration tube (length: $20 \mathrm{~cm}$, outside diameter: $1.9 \mathrm{~cm}$, inside diameter: $1.26 \mathrm{~cm}$ ). Then, the wave tube is connected to the nasal cavity via a beveled nosepiece (material: polyurethane, form: cylindrical, length between top of the wave tube and outlet of the nosepiece: $3.5 \mathrm{~cm}$ ). Three nosepieces are used with an opening diameter of 1.25 to $0.8 \mathrm{~cm}$, 1.25 to $1.1 \mathrm{~cm}$, and 1.25 to $1.3 \mathrm{~cm}$ (Fig. I).
All tests were done by the same operator to minimize the operator bias related to testing procedure.

The subject was asked to let half of his breathe out and then stop breathing and swallowing. The nosepiece was placed gently against the patient's left nostril with bevel sloping down to the right side and the tube parallel to the dorsum of the nose. To stabilize the tube during the test, it was held with thumb and index finger and the other fingers resting on the patient's chin (Figure 2). We apply pressure just sufficient to affect acoustic seal without distorting the nasal vestibule. This is done under careful visual control

- The data were collected just until an audible beep was heard or until a red dot appeared in the upper right corner of the monitor screen (about 4 seconds). Each measurement is repeated four times to ensure accuracy of the technique. Any curve showing significant deviation from the other curves is also discarded.

- To perform the test on the right side, the entire wave tube turned around or the nosepiece twisted around $180^{\circ}$.

- The test was carried out again 15 minutes after nasal decongestant using $\quad 0.05 \% \quad$ oxymetazoline hydrochloride (Afrin) nasal spray. Each nasal cavity was sprayed twice. The nasal spray form was chosen instead of any other form (example nasal drop) to ensure uniform spread of the decongestant all over the nasal cavity.

- We save and archive patient's data before ending the session.

- AR was performed to measure the 
MCA at the anterior 1-5 $\mathrm{cm}$ from the nostril and the volume (NCV) between the nostril and $5 \mathrm{~cm}$ into the nose according to SCAR, 2000 (Standardization Committee on Acoustic Rhinometry). The mean MCA (mMCA; equal to $(\mathrm{L}+\mathrm{R}) / 2$ ), mean DMCA (mDMCA; equal to $(\mathrm{L}+\mathrm{R}) / 2)$, and total volume (tNCV; equal to $\mathrm{L}+\mathrm{R}$ ) were calculated for each subjects, where $\mathrm{L}$ and $\mathrm{R}$ refer to the measurements made for the left and right nostrils respectively.

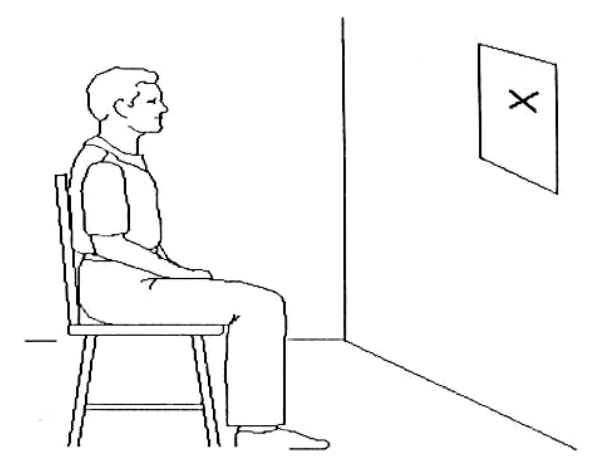

Figure (1): The patient sit upright in a straight backed chair facing straight ahead and fixing his gaze on the sign $X$. The chair is preferably placed in a consistent location.

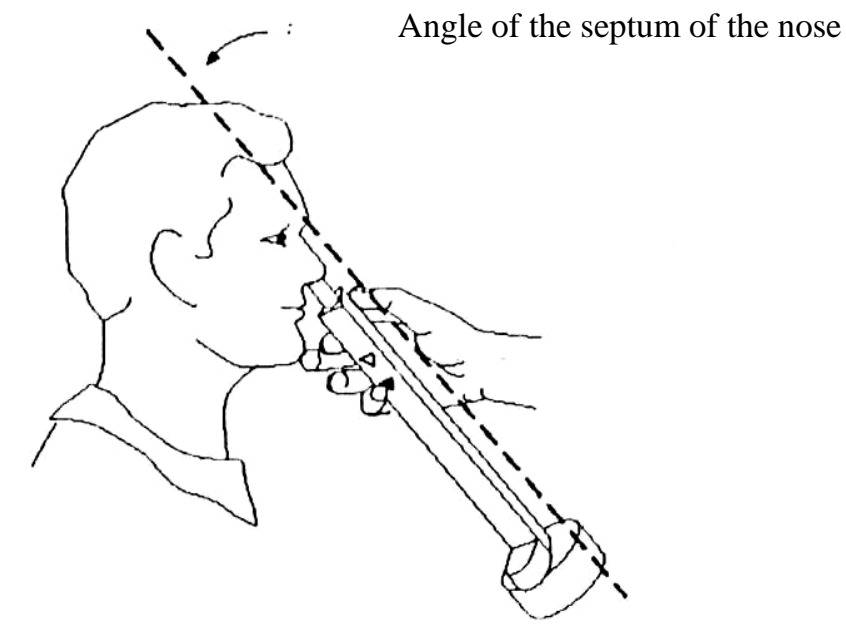

Fig (2): The wave tube was held on the same plane as the bridge of the patient's nose. We hold the tube with thumb and index finger and other fingers resting on the patient's chin. 


\section{RESULTS}

The study included 130 normal young volunteers; 56 subjects from Suez Canal area, 29 subjects from Sinai and 45 subjects from East Delta. From the 130 subjects, 70 were males (54\%) and 60 were females (46\%).

103 of the subjects (79\%) were not aware of the nasal cycle sensation, while 27 of them (21\%) were aware of the nasal cycle sensation.

The mean MCA (mMCA); equal to $(\mathrm{L}+\mathrm{R}) / 2)$, mean DMCA (mDMCA); equal to $(\mathrm{L}+\mathrm{R}) / 2)$, and total volume (tNCV); equal to $(\mathrm{L}+\mathrm{R})$ were calculated for each subjects, where $\mathrm{L}$ and $\mathrm{R}$ refer to the measurements made for the left and right nostrils respectively.

Regarding the AR parameters before decongestion, Table (1) shows the mean, the standard deviation and the range of AR parameters for the 260 cavities before decongestion. The mean mMCA was $0.58 \pm 0.15 \mathrm{~cm}^{2}$ ranging from 0.27 to $1.00 \mathrm{~cm}^{2}$. The mean mDMCA was $1.92 \pm 0.16 \mathrm{~cm}$ ranging from 1.62 to $2.34 \mathrm{~cm}$. The mean tNCV was $12.68 \pm 3.35 \mathrm{~cm}^{3}$ ranging from 5.11 to $21.97 \mathrm{~cm}^{3}$.

Table (1): AR parameters for 260 cavities before decongestion

\begin{tabular}{|l|l|l|l|}
\hline & mMCA $\left(\mathrm{cm}^{2}\right)$ & mDMCA $(\mathrm{cm})$ & tNCV $\left(\mathrm{cm}^{3}\right)$ \\
\hline Mean & 0.58 & 1.92 & 12.68 \\
\hline SD & 0.15 & 0.16 & 3.35 \\
\hline Min & 0.27 & 1.62 & 5.11 \\
\hline Max & 1.00 & 2.34 & 21.97 \\
\hline
\end{tabular}

Before decongestion, the mean mMCA in males was $0.62 \pm 0.14 \mathrm{~cm}^{2}$ ranging from 0.27 to $1.00 \mathrm{~cm}^{2}$, while in females it was $0.53 \pm 0.13 \mathrm{~cm}^{2}$ ranging from 0.26 to $0.81 \mathrm{~cm}^{2}$. The difference between males and females in mMCA was statistically significant ( $p$ value $=0.02)$.

The mean mDMCA was $1.99 \pm$ $0.14 \mathrm{~cm}$ for males ranging from 1.62 to $2.34 \mathrm{~cm}$, while in females it was $1.84 \pm 0.14 \mathrm{~cm}$ ranging from 1.62 to $2.10 \mathrm{~cm}$. The difference between males and females in mDMCA was statistically significant ( $\mathrm{p}$ value = 0.001).
The mean $\mathrm{tNCV}$ was $13.14 \pm$ $3.12 \mathrm{~cm}^{3}$ for males ranging from 5.11 to $21.42 \mathrm{~cm}^{3}$, while in females it was $12.13 \pm 3.53 \mathrm{~cm}^{3}$ ranging from 6.44 to $21.97 \mathrm{~cm}^{3}$. The difference between males and females in tNCV was statistically significant ( $\mathrm{p}$ value = 0.03).

Figure (3) shows the acoustic rhinometry curves before decongestion for left and right nostrils respectively. The curves show the normal ascending $\mathrm{W}$-shape pattern, which indicate that the minimal crosssectional area (MCA) was in the valve region (I notch) not in the inferior turbinate region (C notch). 


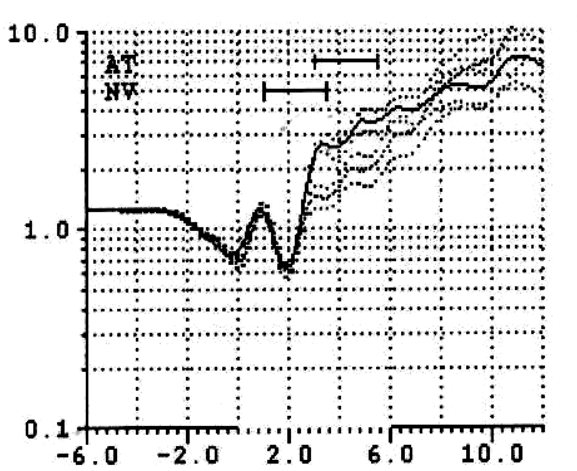

MCA

Left after:

0.63

Right after:

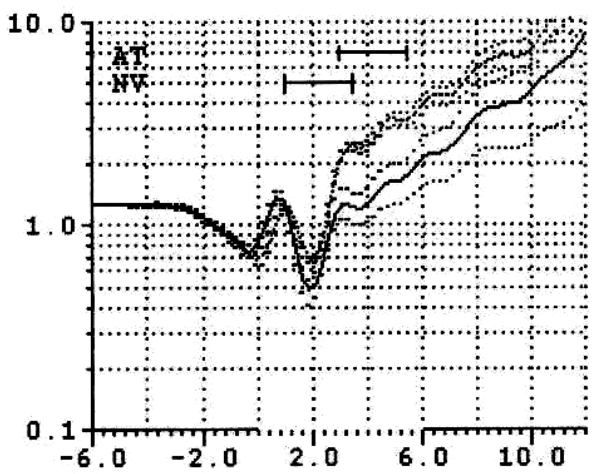

DMCA

NCV

1.86

8.25

1.86

Figure (3): Acoustic rhinometry curves before decongestion for left and right nostrils respectively.

AT stands for anterior turbinate; NV stands for nasal valve

Tables (2) show the mean, the standard deviation and the range of AR parameters for the 260 cavities after decongestion. The mean mMCA was $0.60 \pm 0.14 \mathrm{~cm}^{2}$ ranging from
0.31 to $1.14 \mathrm{~cm}^{2}$. The mean mDMCA was $1.90 \pm 0.18 \mathrm{~cm}$ ranging from 1.50 to $2.46 \mathrm{~cm}$. The mean $\mathrm{tNCV}$ was $13.32 \pm 3.79 \mathrm{~cm}^{3}$ ranging from 5.46 to $26.41 \mathrm{~cm}^{3}$.

Table (2): AR parameters for 260 cavities after decongestion

\begin{tabular}{|l|l|l|l|}
\hline & mMCA $\left(\mathrm{cm}^{2}\right)$ & mDMCA $(\mathrm{cm})$ & $\mathrm{tNCV}\left(\mathrm{cm}^{3}\right)$ \\
\hline Mean & 0.60 & 1.90 & 13.32 \\
\hline SD & 0.14 & 0.18 & 3.79 \\
\hline Min & 0.31 & 1.50 & 5.46 \\
\hline Max & 1.14 & 2.46 & 26.41 \\
\hline
\end{tabular}

Also, after decongestion, the mean mMCA in males was $0.64 \pm$ $0.15 \mathrm{~cm}^{2}$ ranging from 0.31 to 1.14 $\mathrm{cm}^{2}$, while in females it was $0.55 \pm$ $0.12 \mathrm{~cm}^{2}$ ranging from 0.34 to 0.75 $\mathrm{cm}^{2}$. The difference between males and females in mMCA was statistically significant ( $\mathrm{p}$ value = 0.01).
The mean mDMCA was $1.97 \pm$ $0.18 \mathrm{~cm}$ for males ranging from 1.50 to $2.46 \mathrm{~cm}$, while in females it was $1.83 \pm 0.14 \mathrm{~cm}$ ranging from 1.62 to $2.10 \mathrm{~cm}$. The difference between males and females in mDMCA was statistically significant ( $\mathrm{p}$ value = 0.001). 
The mean $\mathrm{tNCV}$ was $14.27 \pm$ $4.18 \mathrm{~cm}^{3}$ for males ranging from 5.46 to $26.41 \mathrm{~cm}^{3}$, while in females it was $12.13 \pm 3.53 \mathrm{~cm}^{3}$ ranging from 6.44 to $21.97 \mathrm{~cm}^{3}$. The difference between males and females in tNCV was statistically significant $(\mathrm{p}$ value $=$ 0.004).

Before and after decongestion we found statistically significant positive correlations between age and all of the AR parameters:

Table (3): Relationship between Age and AR parameters before decongestion

\begin{tabular}{|c|c|c|c|}
\hline \multirow{2}{*}{ AR parameters } & \multicolumn{3}{|l|}{ Age } \\
\hline & $r$ & p-value & Sig. \\
\hline mMCA & 0.189 & 0.032 & + \\
\hline mDMCA & 0.310 & 0.001 & ++ \\
\hline tNCV & 0.261 & 0.003 & ++ \\
\hline
\end{tabular}

Table (4): Relationship between Age and AR parameters after decongestion

\begin{tabular}{|c|c|c|c|}
\hline \multirow{2}{*}{ AR parameters } & \multicolumn{3}{|l|}{ Age } \\
\hline & $r$ & p-value & Sig. \\
\hline mMCA & 0.067 & 0.046 & + \\
\hline mDMCA & 0.195 & 0.026 & + \\
\hline tNCV & 0.235 & 0.007 & ++ \\
\hline
\end{tabular}

Regarding the height, we found statistically significant positive correlations between all the AR parameters and the height either before or after decongestant.

Table (5): Relationship between Height and AR parameters before decongestion

\begin{tabular}{|c|c|c|c|}
\hline \multirow{2}{*}{ AR parameters } & \multicolumn{3}{|l|}{ Height } \\
\hline & $r$ & p-value & Sig. \\
\hline mMCA & 0.305 & 0.001 & ++ \\
\hline mDMCA & 0.537 & 0.001 & ++ \\
\hline tNCV & 0.233 & 0.008 & ++ \\
\hline
\end{tabular}

Table (6): Relationship between Height and AR parameters after decongestion

\begin{tabular}{|l|l|l|l|}
\hline \multirow{2}{*}{ AR parameters } & Height & p-value & Sig. \\
\cline { 2 - 4 } & $\mathrm{r}$ & 0.044 & + \\
\hline mMCA & 0.177 & 0.001 & ++ \\
\hline mDMCA & 0.461 & 0.033 & + \\
\hline tNCV & 0.187 & & \\
\hline
\end{tabular}

Regarding the weight, we found statistically significant positive correlations between all the AR parameters and the weight, either before or after decongestant. 
Table (7): Relationship between Weight and AR parameters before decongestion

\begin{tabular}{|l|l|l|l|}
\hline \multirow{2}{*}{ AR parameters } & \multicolumn{3}{|l|}{ Weight } \\
\cline { 2 - 4 } & $\mathrm{r}$ & $\mathrm{p}$-value & Sig. \\
\hline mMCA & 0.264 & 0.002 & ++ \\
\hline mDMCA & 0.395 & 0.001 & ++ \\
\hline tNCV & 0.170 & 0.04 & + \\
\hline
\end{tabular}

Table (8): Relationship between Weight and AR parameters after decongestion

\begin{tabular}{|c|c|c|c|}
\hline \multirow{2}{*}{ AR parameters } & \multicolumn{3}{|c|}{ Weight } \\
\hline & $r$ & p-value & Sig. \\
\hline mMCA & 0.195 & 0.026 & + \\
\hline mDMCA & 0.321 & 0.001 & ++ \\
\hline tNCV & 0.182 & 0.039 & + \\
\hline
\end{tabular}

It was found statistically nonsignificant difference in all the AR parameters between the group with subjective sensation of nasal cycle and the group without subjective sensation of nasal cycle, either before or after decongestion.
In relation to the sports performance, it was found that mMCA, mDMCA and tNCV, all were higher in the sports performing group compared to the non sport performing group, either before or after decongestion. See table 9 and 10

Table (9): Relation between the AR parameters before decongestion and sport performance

\begin{tabular}{|l|l|l|l|l|}
\hline & $\begin{array}{l}\text { Sport } \\
\text { performance }\end{array}$ & $\begin{array}{l}\text { No sport } \\
\text { performance }\end{array}$ & t-test & P value \\
\hline mMCA $\left(\mathrm{cm}^{2}\right)$ & 0.61 & 0.56 & 2.13 & $0.035^{*}$ \\
\hline mDMCA $(\mathrm{cm})$ & 1.96 & 1.88 & 2.83 & $0.005^{* *}$ \\
\hline tNCV $\left(\mathrm{cm}^{3}\right)$ & 13.35 & 12.19 & 1.96 & $0.051^{*}$ \\
\hline
\end{tabular}

Table (10): Relation between the AR parameters after decongestion and sport performance

\begin{tabular}{|l|l|l|l|l|}
\hline & $\begin{array}{l}\text { Sport } \\
\text { performance }\end{array}$ & $\begin{array}{l}\text { No sport } \\
\text { performance }\end{array}$ & t-test & P value \\
\hline mMCA $\left(\mathrm{cm}^{2}\right)$ & 0.62 & 0.58 & 1.62 & $0.018^{*}$ \\
\hline mDMCA $(\mathrm{cm})$ & 1.95 & 1.86 & 2.82 & $0.005^{* *}$ \\
\hline $\begin{array}{l}\text { tNCV } \\
\left(\mathrm{cm}^{3}\right)\end{array}$ & 13.94 & 12.87 & 1.60 & $0.021^{*}$ \\
\hline
\end{tabular}


Regarding the different phases of the menstrual cycle and AR parameters, it was found that, there were statistically non-significant differences in first half, mid-cycle and second half of the menstrual cycle in all the AR parameters.

Table (11): Relation between the AR parameters before decongestion and phases of menstrual cycle

\begin{tabular}{|l|l|l|l|l|l|}
\hline & First half & Mid-cycle & $\begin{array}{l}\text { Second } \\
\text { half }\end{array}$ & F-test & P value \\
\hline mMCA $\left(\mathrm{cm}^{2}\right)$ & 0.54 & 0.52 & 0.55 & 7.12 & 0.1 \\
\hline mDMCA $(\mathrm{cm})$ & 1.85 & 1.84 & 1.78 & 2.01 & 0.09 \\
\hline tNCV $\left(\mathrm{cm}^{3}\right)$ & 12.47 & 11.47 & 12.18 & 15.76 & 0.07 \\
\hline
\end{tabular}

Table (12): Relation between the AR parameters after decongestion and phases of menstrual cycle

\begin{tabular}{|l|l|l|l|l|l|}
\hline & First half & Mid-cycle & $\begin{array}{l}\text { Second } \\
\text { half }\end{array}$ & F-test & P value \\
\hline mMCA $\left(\mathrm{cm}^{2}\right)$ & 0.57 & 0.54 & 0.58 & 4.74 & 0.06 \\
\hline mDMCA $(\mathrm{cm})$ & 1.82 & 1.84 & 1.76 & 1.78 & 0.14 \\
\hline $\begin{array}{l}\text { tNCV } \\
\left(\mathrm{cm}^{3}\right)\end{array}$ & 12.86 & 12.10 & 12.99 & 17.647 & 0.12 \\
\hline
\end{tabular}

\section{DISCUSSION}

For the past 100 years, physiologists and rhinologists had been interested in the concept of quantifying nasal patency. Several techniques have been developed in the search for a reliable and reproducible method of quantifying nasal patency ${ }^{\mathbf{8}}$.

Acoustic rhinometry provided new parameters for the objective evaluation of nasal patency: MCA, DMCA and NCV. Since its introduction for clinical use by Hilberg et $\mathbf{a l}^{9}$. , it has been used to study the nasal geometry in normal

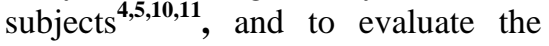
effect of different therapeutic interventions either medical ${ }^{12,13}$, or surgical $^{14,15}$.

Mean values of normal AR parameters were reported differently in various studies. This may be related to different inclusion and exclusion criteria and differences in the technique. Racial anatomic differences do occur in anthropomorphic measurements of the external and internal nasal geometry $^{7,16}$.

The MCA was measured in every nasal fossa separately. Then, the mean MCA (mMCA) was calculated in every individual separately by the following equation ${ }^{5}$ :

mMCA $=$ [MCA of the left side + MCA of the right side] / 2

Then mean mMCA of all individuals was $0.58 \pm 0.15 \mathrm{~cm}^{2}$ (mean \pm SD)with a range 0.27 to 1 $\mathrm{cm}^{2}$ before decongestion and $0.60 \pm$ 
$0.14 \mathrm{~cm}^{2}$ with a range 0.31 to 1.14 $\mathrm{cm}^{2}$ after decongestion.

It was found that the mean mMCA in this study are nearly similar to the mean mMCA for: $\operatorname{Asian}^{16}$, Asian \& White ${ }^{6}$ and Orientals ${ }^{7}$.

The difference between males and females in mMCA is statistically significant $(p<0.05)$ both before and after decongestion which agreed with results of Miliqvist and Bende ${ }^{11}$, and Grymer et al. ${ }^{10}$.

In the contrary, Ho et al. ${ }^{17}$, found that there was no significant difference between Oriental male and female $(p=0.32)$ and also, Corey et $\mathrm{al}^{4}$., and Huang et $\mathrm{al}^{5}$., found that there was no significant difference in MCA between males and females within the same racial group.

In this study, the mMCA shows positive and statistically significant correlation to weight, height and age, before and after decongestion, which agreed the results of Miliqvist and Bende $^{11}$.

In the contrary, Corey et $\mathbf{a l}^{4}$., found that height and weight do not have a significant effect on MCA measurements. Also, Huang et $\mathbf{a l}^{5}$., found that height and weight did not show any significant correlation with MCA.

The DMCA was measured in every nasal fossa separately. Then, the mean DMCA (mDMCA) was calculated in every individual separately by the following equation ${ }^{5}$ :

mDMCA $=$ [DMCA of the left side + DMCA of the right side]/2

The mean mDMCA in this study was $1.92 \pm 0.16 \mathrm{~cm}$ with a range 1.62- $2.34 \mathrm{~cm}$ before decongestion and $1.90 \pm 0.18 \mathrm{~cm}$ with a range
1.50- $2.46 \mathrm{~cm}$ after decongestion. This is the location of the nasal valve (up to $3 \mathrm{~cm}$ ), so when the MCA located in this area this means that the shape of the curve was of ascending type "ascending W"18.

The mean mDMCA in this study was similar to that of: Roithmann et $\mathrm{al}^{14}$; Grymer et $\mathrm{al}^{10}$; ElDemerdash $^{19}$ and the Oriental race in Morgan et $\mathrm{al}^{7}$.

In this study, the difference between males and females in mDMCA was statistically significant $(\mathrm{p}<0.05)$ both before and after decongestion. Also, we found that the mDMCA shows weak positive and statistically significant correlation to weight, height and age, before and after decongestion.

In this study, SCAR (Standardization Committee on Acoustic Rhinometry) guidelines were followed. So, the nasal cavity volume was measured from the nostril to $5 \mathrm{~cm}$ inside the nasal cavity according to Hilberg and Pedersen ${ }^{20}$ who illustrated that beyond this, the accuracy of AR diminishes significantly. The mean tNCV in this study was $12.68 \pm 3.35 \mathrm{~cm}^{3}$ with a range 5.11 to $21.97 \mathrm{~cm}^{3}$ before decongestion and $13.32 \pm 3.79 \mathrm{~cm}^{3}$ with a range 5.46 to $26.41 \mathrm{~cm}^{3}$ after decongestion.

Huang et $\mathbf{a l}^{5}$., studying the nasal cavity of three ethnic groups (Chinese, Malay and Indian) found that the total volume (tNCV) $0-5 \mathrm{~cm}$ from the nostrils as follow: for Chinese: $15.64 \pm 0.92 \mathrm{~cm}^{3}$, for Malay: $14.58 \pm 1.33 \mathrm{~cm}^{3}$ and for Indian: $16.25 \pm 0.96 \mathrm{~cm}^{3}$. The mean $\mathrm{tNCV}$ in this study was different from that of Huang et $\mathbf{a l}^{5}$, although they were 
measured at the same distance (0-5 $\mathrm{cm})$, but this difference may be due to the difference in race.

In this study, the mean tNCV shows weak positive and statistically significant correlation to weight, height and age, before and after decongestion. Huang et $\mathbf{a l}^{5}$., found that tNCV was only significantly correlated with age $(p=0.001)$.

In the contrary, Grymer et $\mathbf{a l}^{\mathbf{1 0}}$, Corey et $\mathrm{al}^{4}$, and Huang et $\mathrm{al}^{5}$, found that height and weight did not show any significant correlation with volume measurements which may be due to difference in sampling design

In this study, only $21 \%(n=27)$ of the study subjects who sense the nasal cycle, although the nasal cycle can be demonstrated in over $80 \%$ of adults but it is unnoticed by the majority of people. The three AR parameters showed statistically non-significant differences between the subjects who were sensing nasal cycle and the subjects who were not, both before and after decongestion. But, the study was not designed and the sample size was not calculated to investigate the differences caused by the nasal cycle. Mennella and Beauchamp ${ }^{21}$ illustrated that; awareness of nasal cycle may come earlier before the sensation of nasal obstruction.

In this study, $42 \%(n=54)$ of the study subjects were performing sport activity. The three AR parameters showed significant difference between the subjects performing sport activity and the subjects who did not, both before and after decongestion; which was in accordance with Yong-Xin et $\mathbf{a l}^{22}$, who explained that exercise decreases the nasal resistance, and increases its patency which was reflected on the AR parameters.

In this study, the females were in different phases of menstrual cycle; about $55 \%$ of the female in the study subjects were in the mid-cycle phase (14-16 days), 23\% in the first half of the cycle (1-13 days) and $22 \%$ in the second half of the cycle (17-28 days). The mMCA and tNCV showed non significant differences between the three phases of the menstrual cycle, both before and after decongestion being at the maximum at both the first and second halves of the cycle where estrogen level is at the minimum and at the minimum in mid-cycle where estrogen level is at the peak. The previous differences were statistically non significant because the sample size had not been calculated according to the menstrual cycle. But, this had a clinical significance as estrogen causes nasal congestion and subsequently the level of estrogen is inversely proportionate to the nasal patency which was reflected on the AR parameters ${ }^{23}$.

\section{REFERENCES}

1- WANG D, PANG $Y$, and YEOH K (1999): Objective assessment of nasal patency- why is it important. Singapore Med J. Vol 40(03): 15-18.

2- DJUPESLAND P. (1996): Acoustic rhinometry. A new method for objective assessment of the nasal airway dimensions. Tidsskr Nor Lageforen. 116(26): 3111-4.

3- FISHER E, LUND V, and SCADDING G (1994): Acoustic rhinometry in rhinological 
practice. J R Soc Med Jul; 87(7): 411-413.

4- COREY P, GUNGOR A, NELSON R, LIU $X$, and FREDBERG J. (1998): Normative standards for nasal cross-sectional areas by race as measured by acoustic rhinometry. Otolaryngol Head Neck Surg 119(4): 389-393.

5- HUANG Z, WANG D, ZHANG $P$, DONG $F$, and YEOH $K$ (2001): Evaluation of nasal cavity by acoustic rhinometry in Chinese, Malay and Indian ethnic groups. Acta Otolaryngol (121):844-848.

6- JURLINA $M$, MADINA $R$, DAWIDOWSKY $K$, IVANKOVIC D, BUMBER Z, and SUBARIC M. (2002): Correlation between the minimal cross-sectional area of the nasal cavity and body surface area. Am J Rhinol (16): 209-213.

7- MORGAN N, MACGREGOR F, BIRCHALL M, LUND V, and SITTAMPALAM $Y$ (1995): Racial differences in nasal fossa dimensions determined by acoustic rhinometry. Rhinol (33): 224248.

8- JONES A, VIANI L, PHILLIPS D, and CHARTERS P (1991): The objective assessment of nasal patency. Clin Otolaryngol (16): 206-211.

9- HILBARG O, JACKSON A, SWIFT D, and PEDERSEN $O$ (1989): Acoustic rhinometry: evaluation of nasal cavity geometry by acoustic reflection. J Appl Physiol. (66): 295-303.
10- GRYMER L, HILBERG O, PEDERSEN $O, \quad$ and RASMUSSEN T (1991): Acoustic rhinometry: Values from adults with subjective normal nasal patency. Rhinology 29(1): 35-47.

11- MILLQVIST E, and BENDE M (1998): Reference values for acoustic rhinometry in subjects without nasal symptoms. Am J Rhinol. (12): 341-343.

12- BACHERT C, WANGENMANN $M$, and VOSSEN-HOLZENKAMP S (1996): Intranasal levocabastine provides fast and effective protection from nasal allergen challenge. Rhinol 34(3): 140-143.

13- MCFADDEN E, GUNGOR A, MAMIKOGLU B, MOINUDDIN R, and COREY J (2000): Laratadine/pseudoephedrine for nasal symptoms in seasonal allergic rhinitis: A double-blind, placebo-controlled study. Ear Nose Throat J 79(4): 254, 257-8, 260.

14- ROITHMANN R, COLE $P$, CHAPNIK J, SHPIRER J, HOFFSTEIN V, and ZAMEL $N$ (1995): Acoustic rhinometry in the evaluation of nasal obstruction. Laryngoscope (105): 275-281.

15- TAKENO S, OSADA $R$, ISHINO $T$, and YAJIN $K$ (2003): Laser surgery of the inferior turbinate for allergic rhinitis with seasonal exacerbation: An acoustic rhinometry study. Ann Otol Rhinol Laryngol (112): 455-460. 
16- BURRES S (1999): Acoustic rhinometry of the Oriental nose. Am J Rhinol 13(5):407-10.

17- HO WK, WEI WI, YUEN AP, and HUI Y (2000): Effect of the external nasal dilator on nasal minimal cross-sectional area in Orientals as assessed by acoustic rhinometry. J Otolaryngol (29): 367-370.

18- PALLANCH J, MCCAFFREY $T$, and KERN $E$ (1998): Evaluation of nasal breathing function with objective airway testing. In: Head and Neck Surgery: Otolaryngology: St. Louis, Mo: Mosby Year-Book; 799-828.

19- EL-DEMERDASH A (2004): Evaluation of nasal patency using acoustic rhinometry for lesion causing nasal obstruction. Thesis submitted in partial fulfillment of MD degree in Otorhionlaryngology, Faculty of Medicine, Suez Canal University.
20- HILBARG O, and PEDERSEN OF (2000): Acoustic rhinometry: Recommendations for technical specifications and standard operating procedures. Rhinol Suppl (16): 3-17.

21- MENNELLA J, and BEAUCHAMP G (1992): Developmental changes in nasal airflow patterns. Acta Otolaryngologica (112): 10251031

22- YONG-XIN SHI, MARGARET SETO-POON, and JOHN R. WHEATLEY (1998): Alae nasi activation decreases nasal resistance during hyperoxic hypercapnia. J Appl Physiol (85): 294-300

23- LYNCH J (2001): Hormonal influences on rhinitis in women. Program and abstracts of 4th Annual Conference of the National Association of Nurse Practitioners in Women's Health. October 10-13, Orlando, Florida. Concurrent Session K.

\section{المعايير الفسيولوجية لقياس ضغط الأنف الرنيني في منطقة قناة السويس}

$$
\begin{aligned}
& \text { أماني عبد الفتاح الباز** - علاء فربد*** - مجدي البربري* - سحر منصور جريث* } \\
& \text { *قسم الفسيولوجى؛ ** *قم الأنف و الأذن و الحنجرة؛ كلية الطب؛ جامعة قناة السويس. } \\
& \text { يقوم جهاز قياس الأنف الرنينى برسم العلاقة بين القطاع العرضى لتجويف الأنف والمسافة داخل الأنف }
\end{aligned}
$$

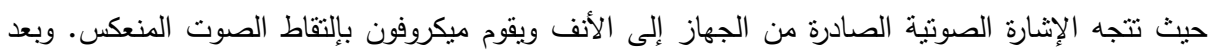

$$
\begin{aligned}
& \text { ذلك يتم تحويلها إلى بيانات رقمية ثم حساب ورسم دالة المساحة فى المسافة للأنف. } \\
& \text { بالرغم أن هناك العديد من الدراسات التي قامت في مصر على جهان فهاز الأنف الرنيني، إلا أنه حتى الآن }
\end{aligned}
$$

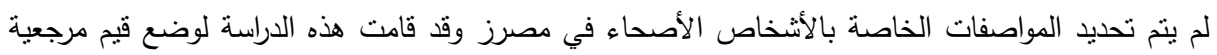

$$
\begin{aligned}
& \text { محلية لقياسات جهاز الأنف الرنينيز }
\end{aligned}
$$




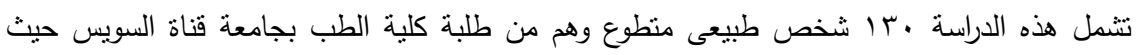

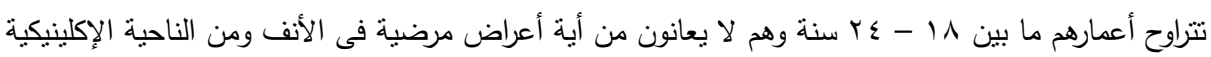

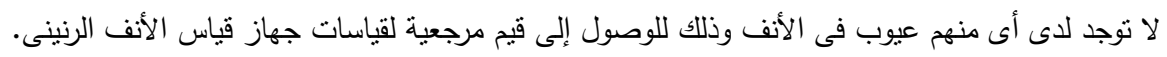

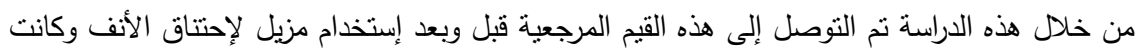

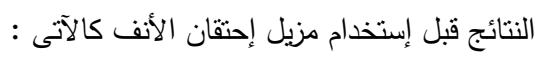

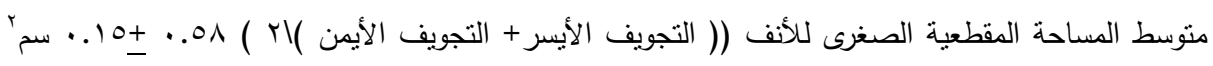

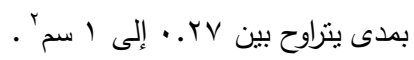

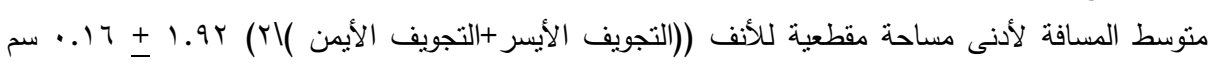

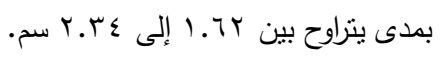

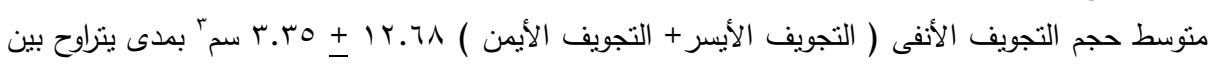

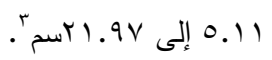
وكانت النتائج بعد إستخدام مزيل إحتقان الأنف كالآتى :

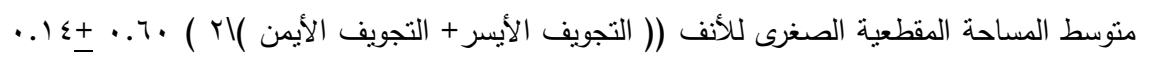

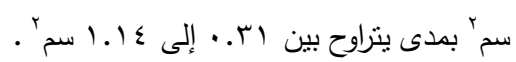

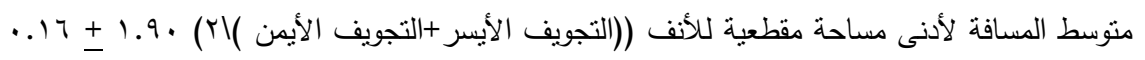

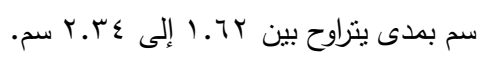

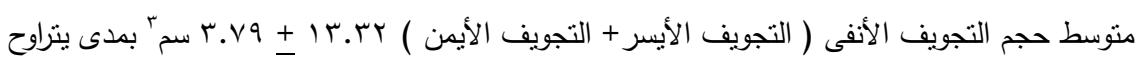

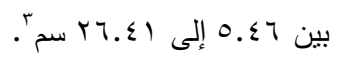
وقد وجد أن الفرق فى قياسات جهاز قياس الأنف الرنينى بين الذكور والإناث لها دلالة إحصائية سواء

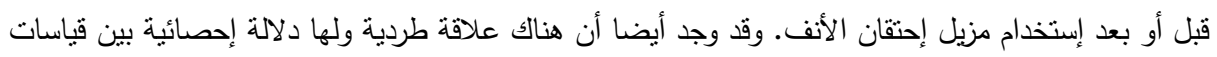

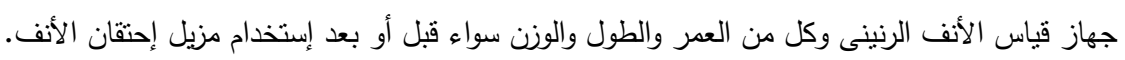

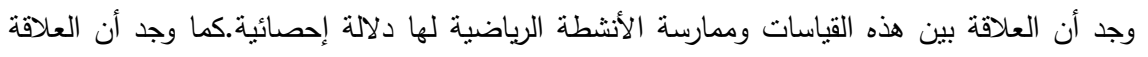

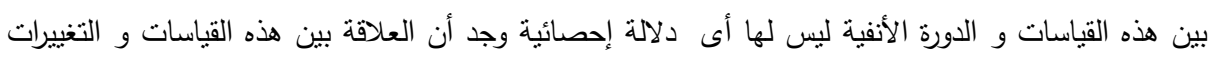
الهرمونية المصاحبة للاورة الثهرية لاى الفتيات أيضا ليس لها ألى دلالة إحصائية.

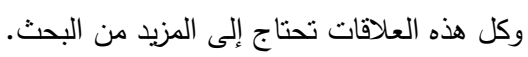

